\title{
A Case of Liver Injury after Exposure to Isopropanol: A Challenging Diagnosis
}

\author{
Daniela Soares Santos ${ }^{\mathrm{a}, \mathrm{b}}$ Ana Luísa Luísa Nunes ${ }^{\mathrm{a}, \mathrm{b}}$ Ana Luísa Matos ${ }^{\mathrm{a}, \mathrm{b}}$ \\ Ana Laic Arsénio Santos ${ }^{a, b}$ Armando Carvalho ${ }^{a, b}$ \\ a Internal Medicine Department, Centro Hospitalar e Universitário de Coimbra EPE, Coimbra, Portugal; \\ b University Clinic of Internal Medicine, Faculty of Medicine, University of Coimbra, Coimbra, Portugal; \\ 'Pathology Department, Centro Hospitalar e Universitário de Coimbra EPE, Coimbra, Portugal
}

\section{Keywords}

Hepatotoxicity · Isopropanol · Hairdresser · Drug-induced liver injury · Occupational liver disease

\section{Abstract}

Drug-induced liver injury is hardly diagnosed, considering not only the wide range of hepatotoxic substances but also the diversity of associated phenotypes and the absence of specific biomarkers. Symptom chronology, drug or toxic exposure, and temporal association help to establish the diagnosis. Exposure to isopropanol has known but rare toxic effects. We report the clinical case of a 33-year-old female hairdresser admitted to the hospital with fatigue, epigastric pain, and jaundice. She presented the following values: aspartate aminotransferase, $485 \mathrm{U} / \mathrm{L}$; alanine transaminase, $908 \mathrm{U} / \mathrm{L} ; \mathrm{ALP}, 240 \mathrm{U} / \mathrm{L} ; \mathrm{GGT}, 370 \mathrm{U} / \mathrm{L}$; total bilirubin, $3.5 \mathrm{mg} /$ $\mathrm{dL}$; and direct bilirubin, $2.1 \mathrm{mg} / \mathrm{dL}$. Albumin, platelet, and INR values were normal. Structural, infectious, immune, and vascular causes were excluded. Liver biopsy was suggestive of toxic hepatitis. A possible association with ibuprofen intake was considered. The patient resumed professional activity, with fatigue and jaundice relapse, as well as a new liver enzyme increase, despite ibuprofen withdrawal. It was concluded that a new hair product containing isopropanol had recently been introduced. As soon as its professional use was discontinued, there was no recurrence of the symptoms. Given the temporal association between the development of acute hepatitis and the use of an isopropanol-containing product, liver toxicity by exposure to isopropanol was assumed. This substance is metabolized in the liver and toxicity may occur by ingestion, skin exposure, or inhalation, and it is described in cases of occupational or accidental exposure. The treatment is symptomatic and comprises toxic suspension.

(c) 2020 Sociedade Portuguesa de Gastrenterologia Published by S. Karger AG, Basel

\section{Um caso de lesão hepática após exposição ao isopropanol: um diagnóstico desafiante}

\section{Palavras Chave \\ Isopropanol · Liver injury · Diagnosis}

\section{Resumo \\ A lesão hepática induzida por tóxicos é um dos distúrbios de mais difícil diagnóstico, quer pela existência de múlti- plos hepatotóxicos, quer pela diversidade de fenótipos associados e ausência de biomarcadores específicos. A cronologia dos sintomas, exposição a fármacos ou tóxicos}

karger@karger.com www.karger.com/pjg

Karger $\stackrel{\text { ' }}{5}$

BOPEN ACCESS
(C) 2020 Sociedade Portuguesa de Gastrenterologia Published by S. Karger AG, Basel

This article is licensed under the Creative Commons AttributionNonCommercial-NoDerivatives 4.0 International License (CC BY NC-ND) (http://www.karger.com/Services/OpenAccessLicense). Usage and distribution for commercial purposes as well as any distribution of modified material requires written permission.
Daniela Soares Santos

Internal Medicine Department, Centro Hospitalar e Universitário de Coimbra Praceta Prof. Mota Pinto PT-3004-561 Coimbra (Portugal)

danielafssantos@gmail.com 
e associação temporal auxilia o diagnóstico. A exposição a isopropanol tem efeitos tóxicos conhecidos e raros. Descrevemos o caso clínico de uma mulher de 33 anos, cabeleireira, admitida por fadiga, epigastralgias e icterícia. Apresentava AST 485 U/L, ALT 908 U/L, FA 240 U/L, GGT $370 \mathrm{U} / \mathrm{L}$, bilirrubina total $3,5 \mathrm{mg} / \mathrm{dL}$ e bilirrubina direta 2,1 $\mathrm{mg} / \mathrm{dL}$; o doseamento sérico de albumina, plaquetas e o valor de INR eram normais. Foram excluídas lesões estruturais, causas infeciosas, imunes e vasculares. Biópsia hepática sugestiva de hepatite tóxica. Considerada possível associação a toma de ibuprofeno. Retomou atividade profissional, com recorrência de fadiga e icterícia, bem como elevação das enzimas hepáticas novamente, apesar de suspensão de ibuprofeno. Apurada exposição a tóxicos profissionais, percebendo-se que o quadro coincidiu com início da utilização de novo produto capilar contendo isopropanol. A doente retomou atividade profissional, não utilizando o produto, sem recorrência. Dada a relação temporal entre o desenvolvimento de hepatite aguda e a utilização de produtos contendo isopropanol, assumiu-se hepatotoxicidade por exposição profissional ao isopropanol. Esta substância é metabolizada no fígado e a toxicidade pode ocorrer por ingestão, exposição cutânea ou inalação, estando descrita em casos de exposição ocupacional ou acidental. $O$ tratamento é sintomático e inclui a suspensão do tóxico.

(C) 2020 Sociedade Portuguesa de Gastrenterologia Publicado por S. Karger AG, Basel

\section{Introduction}

Drug-induced liver injury is one of the most challenging liver disorders because of the myriad of drugs used in clinical practice, the available herbs and dietary supplements with hepatotoxic potential, the ability of the condition to present with a variety of clinical and pathological phenotypes, and the current absence of specific biomarkers. This diagnosis requires a high degree of awareness of the condition and careful exclusion of alternative etiologies. Hepatotoxicity can be severe, leading to acute liver failure [1].

It is known that occupational exposures can induce liver injury in a similar way to prescription drugs; herbal and dietary supplements and workplace exposure have been implicated in the full spectrum of liver disease. A variety of chemicals, including solvents, pesticides, and metals, have been linked to occupational liver diseases [2].

Contact with these hepatotoxic agents may result from occupational exposure. Workplace exposure has been associated with acute and chronic liver diseases. However, its prevalence is inadequately quantified, and their epidemiology is limited [2].

Occupational liver diseases may result from accidental exposure to a significative quantity of product, which is uncommon and easily recognized, or from prolonged lower-level exposures, which is more frequent but often overlooked. Normally, prolonged lower-level exposures have an insidious onset and may be asymptomatic or obfuscated and confounded by concurrent conditions [2].

Isopropanol or isopropyl alcohol (2-propanol) is a volatile liquid that is miscible in both water and organic solvents. Due to its useful properties and low toxicity, isopropanol has been widely used for many years as a solvent, rubbing alcohol, and mild disinfectant. Despite the long experience with its use, the toxicological data on isopropanol has been, until recently, relatively limited [3].

\section{Case Report/Case Presentation}

A 33-year-old Caucasian female hairdresser was admitted to the hospital with fatigue, persistent epigastric pain, and jaundice, which had appeared insidiously 2 weeks before and progressively worsened. She had no fever or urine and stool alterations.

She had been taking ibuprofen $600 \mathrm{mg}$ every $12 \mathrm{~h}$ for the last 2 months for a uterine cervix inflammatory lesion. She had a history of depression and had been medicated with sertraline for 5 years.

On physical examination the patient had jaundice, with no encephalopathy or other alterations, but no other alterations were found. Laboratory tests showed the following values: aspartate transaminase (AST), $485 \mathrm{U} / \mathrm{L}$ (>15× upper limit of normal [ULN]); alanine transaminase (ALT), $908 \mathrm{U} / \mathrm{L}(>20 \times \mathrm{ULN})$; alkaline phosphatase (ALP), $240 \mathrm{U} / \mathrm{L}(2 \times \mathrm{ULN}) ; \gamma$-glutamyltransferase (GGT), $370 \mathrm{U} / \mathrm{L}(>6 \times \mathrm{ULN})$; total bilirubin (TB), $3.5 \mathrm{mg} / \mathrm{dL}(>2 \times \mathrm{ULN})$; direct bilirubin, $2.1 \mathrm{mg} / \mathrm{dL}$; albumin, $3.7 \mathrm{~g} / \mathrm{dL}$; platelets, $160 \mathrm{~g} / \mathrm{L}$; and INR value, 1.29. The abdominal ultrasound with Doppler evaluation was normal. Infectious, metabolic, immune, and vascular causes were excluded.

Liver biopsy revealed: a portal space inflammatory infiltrate with small lymphocytes and eosinophils and focal lesions of the limiting lamina; at the lobular level and predominantly in the 3 acinar zones hepatocyte necrosis with some centrocentral bridges, acidophilic bodies, and mild lymphocytic and granulocytic inflammatory infiltrate; some histiocytic and inflammatory cells in acinar zones 1 and 2; and no deposits of iron (Perls), copper (rhodanine), or hyaline blood cells (PAS-D). Acute lobular and portal hepatitis with confluent centrilobular necrosis was found (Fig. 1). These findings allowed ruling out of other etiologies such as autoimmune or metabolic causes, and a diagnosis of toxic hepatitis was assumed.

Ibuprofen intake was suspended, and she was kept only on symptomatic therapy. The patient slowly improved and at discharge she was asymptomatic and analytical changes were progressively normalizing; the following values were as follows: AST, 324 U/L; ALT, 521 U/L; ALP, 234 U/L; GGT, 330 U/L; TB, 2.9 mg/ $\mathrm{dL}$; and direct bilirubin, $1.3 \mathrm{mg} / \mathrm{dL}$, with normal albumin $(4.2 \mathrm{~g} /$ $\mathrm{dL})$, platelet counts $(215 \mathrm{G} / \mathrm{L})$, and INR (i.e., 1.15). The existence 

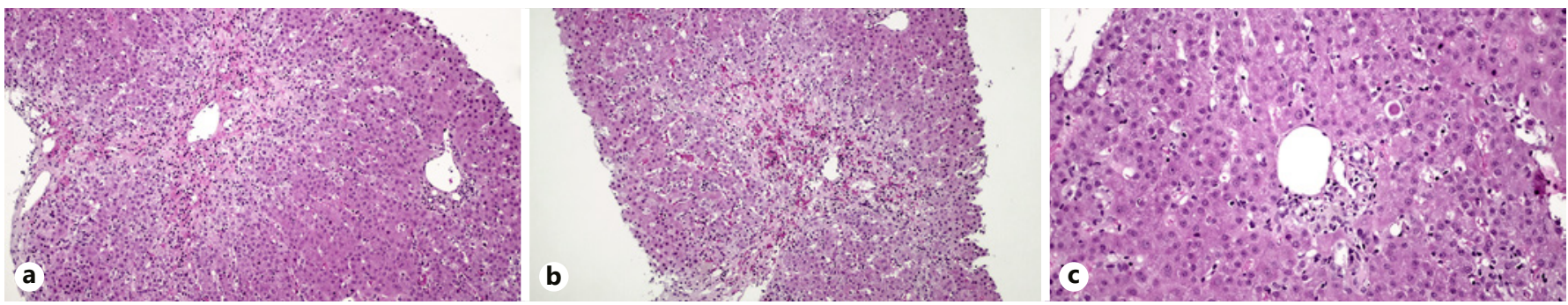

Fig. 1. Liver biopsy. a, b HE. $\times 100$. Lobular region (acinar zone 3 ) with lymphocytic and granulocytic inflammatory infiltrate, with necrotic hepatitis and centrocentral bridges. c HE. $\times 200$. Portal space with lymphocytic inflammatory infiltrate and focal lesions on the limiting lamina, adjacent to an acidophilic body.

of an ibuprofen-induced liver injury was assumed. During the initial follow-up period, analytical values completely normalized.

After returning to her job, she complained of extreme fatigue and, analytically, there was a new worsening, with the following values: AST (289 U/L), ALT (602 U/L), ALP (159 U/L) and GGT (186 U/L) elevation, TB $1.4 \mathrm{mg} / \mathrm{dL}$, direct bilirubin $0.8 \mathrm{mg} / \mathrm{dL}$, and INR 1.13, despite ibuprofen withdrawal. By that time, an occupational exposure was suspected and indeed corroborated after complete clinical and analytical recovery with professional activity suspension and home rest.

Professional toxic chemicals exposure was assessed. It was concluded that the symptoms settled after regular usage of a new permanent hair-straightening product containing isopropanol. Our patient was exposed to this new product on a daily basis. She resumed her craft banning this product and no recurrence was seen after more than 1 year of follow-up.

\section{Discussion/Conclusion}

In the last 30 years, experimental tests have been conducted to evaluate the pharmacokinetics and toxicity of isopropanol. The goal of these tests is to provide the experimental basis for a more confident evaluation of potential human health risks from isopropanol exposure [3].

It is used in body rubs, hand lotions, aftershave lotions, cosmetics, and pharmaceuticals, as well as in antifreeze, industrial solvent, solvent for gums, essential oils and resins, quick-drying inks, and antiseptic and pharmaceutical aids.

Toxic effects have been described in occupational and accidental exposures and include central nervous system depression and liver, kidney, cardiovascular, and brain damage. The absorption can occur by oral intake and dermal or inhalation exposure [4]. In elevated concentrations, particularly ingestion, isopropanol can be lethal.

In the EASL Clinical Practice Guideline, acute liver injury is defined by the presence of any one of the following criteria: ALT $\geq 5 \times \mathrm{ULN}$, ALP $\geq 2 \times \mathrm{ULN}$ (particularly if there is concomitantly elevated GGT in the absence of bone disease), and ALT $\geq 3 \times$ ULN and simultaneous TB $>2 \times$ ULN. Besides that, liver injury can be classified as hepatocellular, cholestatic, and mixed pattern according to the $\mathrm{R}$ value ([ALT/ULN]/[ALP/ULN]) [2].

These definitions allow the identification of an acute hepatic reaction in people exposed to hepatotoxins [2].

The diagnosis of an occupational liver disease relies on a high level of suspicion and there are no pathognomonic signs. Occupational history is essential, and the work environment must be explored, considering that occupational exposure occurs usually by inhalation and through the skin [2].

In our case, the existence of a temporal relationship with the administration of the drug, resolution after withdrawal of the drug, recurrence of the adverse effect after reexposure, and the absence of another alternative cause allowed the diagnosis of isopropanol hepatotoxicity. The patient was exposed to isopropanol by inhalation. Alveolar concentration is correlated to the environmental concentration at any given time. The inhalation exposure to isopropanol varies from 0.4 to $14.8 \mathrm{mg} / \mathrm{m}^{3}$, with a mean of $5.6 \mathrm{mg} / \mathrm{m}^{3}$, for hairdressers in Norway [5].

After absorption, isopropyl alcohol is distributed in body water and $20-50 \%$ is excreted unchanged. Most of it is metabolized in the liver by alcohol dehydrogenase into acetone, formate, and finally carbon dioxide [4]. It is metabolized at a slower rate than ethanol [6]. Acetone is gradually eliminated by the kidneys $(\sim 60 \%)$ or lungs $(\sim 40 \%)$. Clinically insignificant excretion occurs into the stomach and saliva [4].

Isopropanol can cause liver damage itself or increase other drugs' hepatotoxicity. The association between occupational exposure and liver injury has been shown. Lavicoli et al. [7] developed a study where they measured the serum levels of ALT, AST, and GGT in 40 printer 
workers exposed to isopropanol, and they concluded that the serum levels of ALT, AST, and GGT were higher in the exposed workers than in the nonexposed ones. The results of this study showed that the removal of isopropanol from the industry had a positive health effect, improving the hepatic function of the workers [7]. Even isopropanol in small concentrations, particularly in prolonged exposures, can cause damage [8].

In our case, the diagnosis was not easy but, in order to establish causality, a coherent synthesis was made between the characteristics of the patient's disease, the exclusion of other liver disorders, collection of a thorough occupational history, the presence of hepatotoxic chemicals, and their known capability to cause that disease. Besides that, we noted recurrent acute liver injury episodes, occurring after reexposure to isopropanol at work, and resolution of symptoms and normalization of blood tests after exposure cessation.

In conclusion, there are no specific biomarkers for the diagnosis and no specific treatment. A high clinical suspicion is essential for the diagnosis. Treatment is symptomatic and decontamination guaranteed.

\section{Statement of Ethics}

Written informed consent was obtained. This study did not require review or approval by the appropriate ethics committee.

\section{Conflict of Interest Statement}

The authors have no conflict of interests to declare.

Funding Sources

None.

\section{Author Contributions}

Daniela Soares Santos and Ana Luísa Nunes drafted this paper. Ana Lai took the histology photos and draft their captions. Ana Luísa Matos, Arsénio Santos, and Armando Carvalho revised this paper critically. All of the authors commented on drafts of this paper. All of the authors have approved the final version of this work.

\section{References}

1 Andrade RJ, Aithal GP, Björnsson ES, Kaplowitz N, Kullak-Ublick GA, Larrey D, et al.; European Association for the Study of the Liver. Electronic address: easloffice@easloffice.eu; Clinical Practice Guideline Panel: Chair; Panel members; EASL Governing Board representative. EASL Clinical Practice Guidelines: drug-induced liver injury. J Hepatol. 2019 Jun;70(6):1222-61.

2 La Vecchia C, Lotti M, Lucena MI, Stove C, Paradis VEuropean Association for the Study of the Liver. Electronic address: easloffice@ easloffice.eu, et al.; EASL Governing Board representative. EASL Clinical Practice Guideline: occupational liver diseases. J Hepatol. 2019 Nov;71(5):1022-37.
3 Clewell HJ 3rd, Gentry PR, Gearhart JM, Covington TR, Banton MI, Andersen ME. Development of a physiologically based pharmacokinetic model of isopropanol and its metabolite acetone. Toxicol Sci. 2001 Oct;63(2): $160-72$.

4 World Health Organization. International Programme on Chemical Safety: poisons information monograph 290 - isopropyl alcohol. Geneva: WHO; 1990. p. 1-36.
5 Hollund BE, Moen B. Prevalence of airway symptoms among hairdressers in Bergen, Norway. Ann Occup Hyg. 1998;42:277-81.

6 Litovitz T. The alcohols: ethanol, methanol, isopropanol, ethylene glycol. Pediatr Clin North Am. 1986 Apr;33(2):311-23.

7 Iavicoli I, Fontana L, Iavicoli S. Modifications of hepatic transaminases in workers exposed to low doses of isopropanol. G Ital Med Lav Ergon. 2007 Jul-Sep;29(3 suppl):271-2.

8 Rajabally YA, Mortimer NJ. Acute neuropathy and erythromelalgia following topical exposure to isopropanol. Vet Hum Toxicol. 2004;46(1):24-5. 